\title{
Behavior Analysis of Traders Regarding Waste Management In The Wonodri Market In Semarang
}

\author{
Ririn Wahyuni ${ }^{1, *}$, Purwanto $\mathrm{AP}^{2}$, and Hartuti Purnaweni ${ }^{3}$ \\ ${ }^{1}$ Master Program of Environmental Science, School of Postgraduate Studies, Diponegoro University, Semarang - Indonesia \\ ${ }^{2}$ Department of Medical science, Faculty of medical school, Diponegoro University, Semarang - Indonesia \\ ${ }^{3}$ Department of Environmental Science, School of Doctoral Studies, Diponegoro University, Semarang - Indonesia
}

\begin{abstract}
This research was conducted to describe the behavior of a trader regarding waste management in the Wonodri Market because there are still many traders who do not care about environmental hygiene related to the management of waste produced, such as disposing of trash leftover from the merchandise in an arbitrary manner and indifference from a trader to waste management. Therefore, an analysis of the behavior of traders is needed, one of which is related to independent waste management carried out by market traders. The method used is field survey, observation of market conditions, and literature study. The results showed that the behavior analysis of traders related to waste management in Wonodri Market was still not perfect, it was shown by the presence of piles of garbage in the kiosk/kiosk aisle, and the behavior of traders who still collected garbage mixed with each other in various compositions. This shows that traders care about waste management is still lacking. The level of education and environment of a trader greatly influences the knowledge and perceptions of traders in waste management in the Wonodri Market. The behavior of traders greatly influences the maintenance of a clean, comfortable and safe market environment, so that it does not hinder the buying and selling process between sellers and buyers and does not break the economic chain that occurs.
\end{abstract}

Keywords: Throw Rubbish; Traders; Markets; Waste Management.

\section{Introduction}

Traditional market is a market that has been known for a long time since tens of centuries ago, estimated to have emerged since the 5th century AD (Anno Domini) in the era of the Kutai Kertanegara kingdom with a barter transaction system. Since that time until now, the market has been used as a venue for meetings from all corners of the village, information exchange, and the place for deep interactions between sellers and buyers through bargaining activities, and continuous visits. Socio-Economic Functions in Traditional Markets according to Noor [1] are market functions that are divided into two, namely: social functions and economic functions. Traditional market social functions, namely as a place to strengthen social relations between traders and buyers, exchange information, learning, and as a means of socialization. The function of the traditional market economy for the community is as a center for buying and selling and providing ease of access to the community, opening jobs for the surrounding community, and increasing community welfare, especially economic income.

The market is an economic activity which is one of the applications of human adaptation to its environment. This is based on the development of increasing and diverse human needs. One problem that is quite complicated to describe is the problem of garbage in the market, besides the relatively large number and having its problems, these conditions often occur in traditional markets whose function is as an economic forum, buying and selling activities which can indirectly cause landfills. Waste management performance in the market according to 2 Rondiyah [2] is merchant awareness or participation in handling individual waste by traders and payment of merchant fees/levies for cleaning and rental costs, availability of cleaning staff in personnel aspects, availability of infrastructure (trash can), toilets, prayer rooms, parking lots, etc.) and the capacity of garbage collection centers, the distance of waste transportation, and the role/responsibilities of manager to supervise the implementation of waste management.

\footnotetext{
*Corresponding author: ririnwahyuni94@gmail.com
} 
According to Lestari [3] The effectiveness of waste management policies is influenced by several supporting factors and inhibiting factors, namely: supporting factors: waste sorting education from MWB (Malang Waste Bank), training and seminars, support, awards and socialization; inhibiting factors: limited public knowledge about effective and efficient waste management, limited budgets, limited facilities and infrastructure, limited skills and ability to capture opportunities. Based on several considerations that the condition of waste management still has high complexity, it is necessary to involve several related components, such as local government agencies, and other stakeholders by considering the environmental conditions around the market, the behavior of traders, facilities and related organizations [4].

The Wonodri market is located in the southern Semarang sub-district, which is in Wonodri urban village and has a land area of 2,000 square meters. The occupancy density of street vendors (street vendors) in the Wonodri Market is approximately 235 traders. In connection with these conditions, several problems arise in the management of market waste based on the behavior of traders in the market Wonodri Semarang, which includes:

1) The trader's Perceptions in disposing of garbage in the Wonodri Market

2) The Practice of traders in the implementation of market waste management in the Wonodri Market. Market waste management is inseparable from the role of a trader in managing and maintaining the cleanliness of the environment around the place of business and the behavior of a trader against garbage before disposal. So, the success of waste management will be felt by traders, communities and the environment around the market. The effectiveness of waste management is influenced by several factors, which are related to organizational problems, facilities and infrastructure of garbage collection, institutional and service-related efforts (Dinas Kebersihan dan Pertamanan) in increasing community knowledge, awareness and concern, especially market traders, and coordination between related work units in waste management, schedules for collecting, transporting, eliminating waste, increasing worker welfare, as well as the level of education and number of members [5].

\section{Traders Behavior}

\subsection{Definition of Knowledge}

Knowledge is a fundamental thing for someone to produce a perception that is then manifested in action. According to Notoatmodjo (2005) [6], there are several factors that influence knowledge, namely: a) Education is an effort to develop personality and abilities both inside and outside the school which then lasts for a lifetime.

b) The source of information/public media is a source of public communication facilities that have a major influence on the formation of opinions or perceptions and beliefs of people.

c) Social, economic and cultural, traditions, habits of people without going through reasoning, whether done good or bad.

d) Environment is everything that exists around individuals, both physical, biological and social environment.

\subsection{Definition of Perception}

Perception is also one of the behavior components that have a very important role in decision making. perception is a process that involves the entry of information or messages into the human brain. Through human perception, it is constantly making connections with its environment. Perception can be interpreted as a cognitive process from someone to the environment that is used to interpret the surrounding environment.

\subsection{Definition of Trade Behavior}

A person's behavior is strongly influenced by 3 factors, namely: (predisposing factors) in the form of knowledge, attitudes, beliefs, values, perceptions, socio-economic, age, gender and related to individual motivation; (enabling factors) manifest in the form of availability of resources, costs, accessibility, referrals, rules/law, skills, officer behavior, market manager's behavior, resources or expertise; (reinforcing factors) found in the physical environment, namely: the behavior of officers, friends, parents, entrepreneurs, and so on [7]. Environment is also a factor that influences changes in a person's behavior. In addition, it also provides an important role, because the environment can form a person's awareness, concern and attitude towards waste management in the vicinity.

\subsection{Definition of Waste Management}

According to Koesmantoro in [8] stated that on the basis of waste management there are 2 kinds of waste management, namely management/handling of local waste (individual) and centralized waste management for a residential or urban environment. The handling of local waste is intended to be carried out by the waste producer by planting it in the excavation of his yard or in other ways that can still be justified. The form of cleanliness of the surrounding environment is one of them is the management of market waste by 
traders by looking at traders' habits in collecting, separating waste and providing independent waste bins. Market waste management efforts are carried out so that the behavior of traders always cares about the environment, especially waste management, where he conducts trade activities and keeps the market environment clean. Therefore it is necessary to conduct research to identify and analyze the behavior of traders related to waste management in the Wonodri market.

\section{Methodology}

\subsection{Time and Place}

This research study is located in South Semarang urban village, Semarang City. The field survey was conducted on March 17, 2019 and April 16, 2019. The research method consisted of methods of observation, interviews, and literature study. The unstructured interviews were done with the related parties (wonodri market manager). The observation was conducted to observe the condition of waste management in the Wonodri market and literature studies were used to support the research. The target of this study was 94 wonodri market traders. Respondent selection was done by using purposive sampling methods, in which the sample was chosen randomly for a certain purpose. The sampling process is determined based on consideration of inclusion criteria that have been determined by researchers, both those directly involved and those who play a role in the implementation of a market. Criteria: Willing as a Respondent, Willing to spend time, selling less than 5 years, Market Manager, Responsible for Market Waste Management in Wonodri Market The location can be seen in Figure 1.

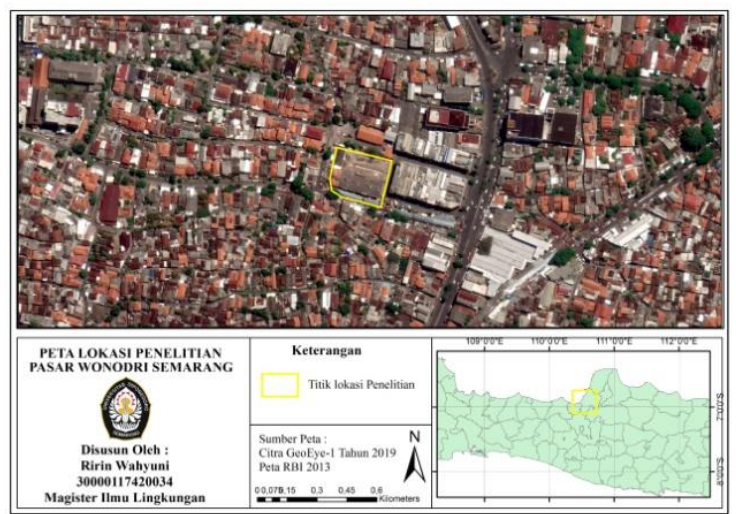

Fig. 1. Research Study Location in the Wonodri Market, Semarang city

\subsection{Tools and Materials}

The material used in the research is the Citra GeoEye- 1 year 2019. Then the image data is displayed using ArcGIS 10.4

\section{Results and Discussion}

\subsection{Environmental Conditions of the Wonodri Market}

Geographically, the Wonodri Market is located near the center of Semarang and is located in the Wonodri sub-district, South Semarang sub-district, Semarang City. The position of the Wonodri Market is between shops in the Wonodri village and is on a road that connects between the villages of Wonodri and Peterongan. Physically Wonodri market consists of 3 floors, namely: ground floor, first floor, and second floor.

Wonodri Market is a relocation from the Wonodri Tempel market was originally a market that was along the wonodri road section every morning, then the passage of time due to the existence of the market caused traffic congestion or congestion because of its location on the fork in the road. And due to unfavorable environmental conditions when viewed in terms of environmental hygiene and infrastructure facilities, the market is dedicated and a special Wondri Market building is built which is currently occupied by traders. However, in Wonodri Market traders only provide daily necessities such as food, household and food needs.

\subsection{Waste Management System in Wonodri Market}

\subsubsection{The Number and Type of Merchant Business}

The number of occupancy density of street vendors (street vendors) in the Wonodri Market is approximately 235 (two hundred thirty five) traders who sell around and within the Wonodri Market. Based on the types of traders in Wonodri market there are two types, wet traders and dry traders. The occupancy rate of each floor in Wonodri market is the ground floor of 100 traders, the first floor is 102 traders and the second floor is 33 traders. The division between the floors is the ground floor for meat and fish traders, the first floor is for vegetable traders and packaged traders, while on the second floor is occupied by fruit traders, market snacks and food. Apart from traders selling food and daily necessities, unique on the ground floor, there are only 2 traders who sell clothes. The number of traders selling in the Wonodri Market cannot be ascertained by the number of traders based on the type of business each day which is caused every day is always their traders who are on holiday or not selling, so the amount sometimes decreases. 


\subsubsection{Waste Management in Wonodri Market}

Based on market management regulations on the policy of waste management in Wonodri Market, it is to ensure market cleanliness and how managers can serve traders well, the market manager takes a policy to collect fees for cleaning costs of Rp. 3000 per kiosk every day. Near from the market location of Wonodri there are available TPS (Temporary Shelter) in the form of 1 container truck provided by DLH (Environmental Agency). Although TPS has been provided in the form of container trucks outside the market, however, on every floor there are no trash bins that are used to hold the remnants of merchandise that shows the separation of waste, between wet and dry or between organic and inorganic. So that the traders only collect the garbage beside the place they sell, and there are also some traders who let the garbage scattered just after they sell, and there are also those who collect garbage together without caring about the selection of garbage and waste management.

Based on information from the Department of Environment that the container truck provided will transport garbage in the afternoon or in the morning, which is then taken to the Final Disposal Site (JPA) in Jatibarang. Market waste management in Wonodri market has the potential to be managed effectively because traders in Wonodri market have supporting facilities (buildings, kiosks/toilets, toilets, bathrooms, prayer rooms, temporary garbage collection container trucks (TPS), and management offices) that can be utilized. With the availability of these facilities, traders should be aware of caring for, maintaining and caring for waste management so that the condition of cleanliness of the market environment is maintained.

\subsection{Traders Perception}

The results of the interview concluded that to the perceptions of traders in maintaining the cleanliness around the kiosks/stalls, each is carried out at any time by means of each garbage being washed or cleaned and then stored in the trash that has been provided by each trader, but there are also traders who only collect near the kiosk / los. There are $10 \%$ traders who prepare trash cans in front of or side of the kiosks/kiosks each to be used for one day then taken by janitors every day to be collected at TPS (Temporary Shelter) in the form of containers near the market. However, $40 \%$ traders did not clean the kiosks/booths occupied.

The merchant's perception of who is responsible for waste management in the Wonodri market is someone who is in charge of managing waste management in the Wonodri market, namely the market leader who regulates and directs traders to consciously and jointly manage waste and maintain a clean environment around the area wonodri market. Trash traders are taken by janitors once a day, namely at 10:00 to $11: 00 \mathrm{WIB}$, the garbage is taken during the day - not necessarily taken away, but has a reason that is not to disturb the activities of traders and buyers in the morning, and so that in the morning the Wonodri market is clean and tidy from garbage.

Based on the results it was found that there were $10 \%$ traders in the Wonodri market who already knew the difference between the types of market waste generated from trading activities. The rubbish includes wet waste in the market Wonodri are leftover vegetables, leftover fruit, leftover meat, and the rest of the fish. The traders also agreed that every trader must know how to do good waste management so that the trader knows the impact of the remaining waste produced. However, in practice in the field of traders' concern for waste, they are still relatively unconcerned because they do not sort out the waste before disposal, there are also traders who care and separate.

\subsection{Trader Behavior}

According through the traders in wonodri market, they don't need to do waste sorting by its types, because of the waste produced by some traders most of it only in one type according to each type of merchandise. After the market activities were completed, some traders, collected their merchandise in front of their kiosks so that the janitors could easily transport it, but there were also many traders who just returned home without caring about the waste produced from the rest of the trade. Differences in behavior between traders are influenced by two factors, namely the knowledge factor, among others, the level of education, source of information, social, economic, cultural, and environmental; and perception factors. The merchant's indifference behavior should be noticed by the department or related parties so that waste management is more effective and the condition of cleanliness of the environment around the market is maintained. The lack of discipline of the traders and managers in carrying out waste management as well as supervising waste disposal as well as the facilities for providing waste bins based on their types has caused the waste management to be handled by traders is still not good. Although there are already regional regulations governing waste management in the market.

Provision of temporary trash bins both independently by traders and market managers should be coordinated so that the behavior of traders regarding waste management is more coordinated. With the commitment and cooperation between the market manager and Wonodri market 
traders about waste management to maintain market cleanliness from various types of waste. In general, the traders are aware, but lack of discipline voluntarily clean up the garbage around each kiosk/kiosk by collecting and storing rubbish in a container that is provided independently and then placed in front of each kiosk/kiosk every day. It is evident that there is still trash scattered and piled up in the stalls/kiosks. The official has provided facilities by providing TPS (Temporary Shelter). Despite the visible service efforts of the related parties, but the behavior of traders in terms of sorting waste and the management who do not provide trash bins for the separation between organic and inorganic or wet with dry ones causes the behavior of traders who do not know the right and correct ways to manage waste.

\section{Conclusion}

Based on the discussion, the research shows that the behavior of traders in the Wonodri market is not perfect, because some traders still collect waste mixed without sorting first, some traders still do not care about the condition of cleaning around the kiosks/stalls, especially related to waste management, and there are still some traders which do not provide garbage containers/bags independently. The unavailability of organic and inorganic waste bins provided by the management.

The perception in question is the perception of the market traders Wonodri that is not regular and has not been disciplined in maintaining cleanliness around the market by disposing of garbage, traders assume that there is no need to sort waste by type. The environment in question is even though there are $10 \%$ of traders who carry out waste management by sorting garbage, separating, and collecting and providing garbage containers/bags, but if no supervision or cooperation is carried out by related parties or the market management will not work with good and will not produce a correct behavior, because behavior is determined by the surrounding environment, one of which is cooperation between parties.

The facility in question is the need to provide trash bags/containers by the market management which is then intended for each trader so that traders feel cared for and supervised to carry out waste management independently, by collecting garbage produced by each trader then stored in containers shared by market managers.

\section{References}

1. TR. Noor, Fungsi Sosial-Ekonomi Pasar Tradisional (Studi Tentang Pasar Karah, Kec. Jambangan, Kota Surabaya) (ID), An Najah Indonesia Mandiri. 5, 1 (2017)
2. Rondiyah, Faktor-Faktor Yang Mempengaruhi Kinerja Pengelolaan Sampah Di Pasar Banjarsari Kota Pekalongan, Jurnal Kesehatan Masyarakat (e-Journal), 2, 3 (2014)

3. AP. Lestari, Program Inovasi Pengelolaan Sampah Di Kota Malang (ID). Universitas Brawijaya Malang, Jurnal Administrasi Publik (JAP), 2, 3: 571-577 (2013)

4. Enri Damanhuri and Tri Padmi, Diktat Kuliah TL-3104 Pengelolaan Sampah, Edisi Semester I - 2010/2011, Program Studi Teknik Lingkungan. Fakultas Teknik Sipil dan Lingkungan, Institut Teknologi Bandung (2010)

5. Sudarto, Keefektivan Pengelolaan Sampah Kota Dalam Meningkatkan Kualitas Lingkungan Di Kecamatan Kajen Kabupaten Pekalongan Tahun (ID), TESIS Program Pascasarjana Universitas Sebelas Maret. Surakarta (2008)

6. S. Notoatmodjo, Metode Penelitian Kesehatan, Edisi Revisi. Rineka Cipta, Jakarta (ID). (2005)

7. L. Green, and M. Kreuter, Health Program Planning: An Educational and Ecological Approach, 4th Edition, McGraw Hill, New York. (2005)

8. Tosepu Ramadhan, Kesehatan Lingkungan, Kendari: Penerbit Bintang Surabaya (ID), 59 (2010) 